\section{Postgraduate Course in Polymer Science}

The thirteenth presentation of this course, offered at the Institute of Macromolecular Chemistry, Academy of Sciences of the Czech Republic, Prague, Czech Republic, has been in progress since October 2008 and will end with a final seminar in July 2009. IUPAC support has enabled the organizers to increase the number of students participating in the course to eight. The lecture course of 50 hours in advanced polymer science is still in progress. Most of the time, the students work on research projects under the supervision of senior scientists of the institute. The names of the students, their home countries, their project titles, and names of their supervisors are as follows:

\begin{tabular}{|c|c|}
\hline Student (Country): Project & Supervisor \\
\hline $\begin{array}{l}\text { Mohammed El Amine Belaouedj } \\
\text { (Algeria): Biomaterials for Tissue } \\
\text { Engineering }\end{array}$ & Dr. Jiri Michalek \\
\hline $\begin{array}{l}\text { Patrycja Bober (Poland): Synthesis and } \\
\text { Characterization of Polyaniline and lts } \\
\text { Nanostructures }\end{array}$ & Dr. Jaroslav Stejskal \\
\hline $\begin{array}{l}\text { Katarzyna Depa (Poland): Hybrid } \\
\text { Materials and Hydrogels }\end{array}$ & Dr. Adam Strachota \\
\hline $\begin{array}{l}\text { Bojan Dimzoski (Macedonia): Rheology } \\
\text { and Phase Structure of Immiscible } \\
\text { Polymer Blends }\end{array}$ & Prof. Ivan Fortelny \\
\hline $\begin{array}{l}\text { Ricardo Kejtek Donato (Brazil): } \\
\text { Nanocomposite Systems Based on } \\
\text { Organic-Inorganic Polymers }\end{array}$ & Dr. Libor Matejka \\
\hline $\begin{array}{l}\text { Alessandro Jager (Brazil): Design, } \\
\text { Preparation, and Characterization of } \\
\text { Polymeric Nanoparticles for Biological } \\
\text { and Technical Applications }\end{array}$ & Dr. Petr Stepanek \\
\hline $\begin{array}{l}\text { Samrana Kazim (India): Plasmonic } \\
\text { Polymer Nanocomposites for } \\
\text { Optoelectronic Applications }\end{array}$ & Dr. Jiri Pfleger \\
\hline $\begin{array}{l}\text { Valentin Sukhanov (Russia): Multiphase } \\
\text { Matrix Nanocomposites: FEM Modeling }\end{array}$ & Dr. Ivan Kelnar \\
\hline
\end{tabular}

More than half of the projects are likely to be published in international journals or communicated at meetings. Detailed information about the course can be found at <www.imc.cas.cz/en/imc/unesco.html>.

Cumulative results from the 13 times the course has been offered so far include 104 graduates and current students; 16 nationalities represented; 132 publications in international journals; 187 communications at international meetings; and 1169 citations, excluding self-citations (as of December 2008).

For more information and comments, contact Task Group Chair Pavel Kratochvil $\langle$ krat@imc.cas.cz〉.

www.iupac.org/web/ins/2007-049-1-400

\section{Toward a Comprehensive Definition of Oxidation State}

The purpose of this two-year project is to obtain a comprehensive definition of the term "oxidation state," which is the oxidation number of an atom in a molecular entity or an extended structure. An algorithm and its validity limits for unambiguous evaluation of the oxidation state/number will be worked out. A glossary of related terms will be produced. The project will review and evaluate the currently used definitions of oxidation state/number in textbooks and articles. These electron-counting schemes will be scrutinized for universality on chemical entities, such as uncharged and charged atoms and molecules (simple or clusterlike, ions or radicals) as well as extended structures, in order to determine whether a simple algorithm is applicable and what its validity limits are. After a reviewing process, the report will eventually be submitted as Recommendations for Pure and Applied Chemistry. Relevant definitions on the IUPAC Gold Book website will be updated.

The members of the task group are all professors with long-term experience in teaching relevant parts of chemistry: Patrick McArdle, Galway, Ireland (organometallic chemistry); Reinhard Nesper, Zürich, Switzerland (inorganic and nanochemistry); Josef Takats, Edmonton, Canada (inorganic and organometallic chemistry); Kazuyuki Tatsumi, Nagoya, Japan (clusters and organometallics); and Pavel Karen, Oslo, Norway (inorganic and solid-state chemistry).

For more information and comments, contact Task Group Chair Pavel Karen <pavel. karen@kjemi.uio.no>.

Cin. www.iupac.org/web/ins/2008-040-1-200 